Available online at https://jurnal.stmikroyal.ac.id/index.php/jurdimas

\title{
PELATIHAN PEMANFAATAN MANAJEMEN REFERENSI ZOTERO
}

\author{
Nurul Izzah ${ }^{1^{*}}$, Rini Hayati Lubis ${ }^{1}$ \\ ${ }^{1}$ Program Studi Ekonomi Syariah, Institut Agama Islam Negeri Padangsidimpuan \\ email:*nurulizzah@iain-padangsidimpuan.ac.id
}

\begin{abstract}
Training on the use of Zotero reference management aims to improve the ability of students of the Faculty of Economics and Islamic Business to use the Zotero application in writing their thesis. This activity is based on the needs of students in managing references and citations used in completing scientific papers or theses. The training method is carried out in several stages starting from planning, implementation and evaluation. More training is carried out starting with the explanation of the material and continuing with practical activities. The results of this training indicate that the ability of students who take part in the training increases in using the Zotero application. The ability of students also increases in managing references and determining appropriate references to be cited in scientific papers.
\end{abstract}

Keywords: reference management; training; Zotero

\begin{abstract}
Abstrak: Pelatihan pemanfaatan manajemen referensi Zotero bertujuan untuk meningkatkan kemampuan mahasiswa Fakultas Ekonomi dan Bisnis Islam dalam menggunakan aplikasi Zotero dalam penulisan skripsi. Kegiatan ini didasari oleh kebutuhan mahasiswa dalam mengelola referensi dan sitasi yang digunakan dalam menyelesaikan karya ilmiah atau skripsi. Metode pelatihan dilakukan dengan beberapa tahapan yang dimulai dari perencanaan, pelaksanaan dan evaluasi. Pelatihan lebih dilakukan dimulai dengan penjabaran materi dan dilanjutkan dengan kegiatan praktek. Hasil pelatihan ini menunjukkan bahwa kemampuan mahasiswa yang mengikuti pelatihan meningkat dalam memanfaatkan aplikasi Zotero. Kemampuan mahasiswa juga semakin meningkat dalam mengelola referensi serta menentukan referensi yang tepat yang akan disitasi dalam karya ilmiah.
\end{abstract}

Kata Kunci: manajemen referensi; pelatihan; Zotero

\section{PENDAHULUAN}

Karya ilmiah merupakan suatu tulisan yang didasarkan pada hasil penelitian dan dipublikasikan dalam bentuk artikel. Karya ilmiah bermacam ragam, seperti skripsi, tesis, laporan riset, jurnal dan lainnya. Di perguruan tinggi, setiap mahasiswa diwajibkan membuat karya tulis ilmiah yang dijadikan sebagai syarat dalam menyelesaikan perkuliahan. Sehingga kemampuan menulis karya ilmiah menjadi hal yang sangat penting bagi setiap mahasiswa. Saat ini, telah banyak perguruan tinggi telah mewajibkan untuk mempublikasi hasil karya ilmiah mahasiswa baik dalam bentuk jurnal atau skripsi.

Permasalahan yang sering dialami oleh mahasiswa dalam proses menyelesaikan skripsi diantaranya kurangnya kemampuan dalam mencari, menentukan dan menyimpan referensireferensi yang akan disitasi. Kemampuan 
mengelola referensi menjadi sangat penting untuk menghasilkan karya ilmiah yang berkualitas. Seiring dengan perkembangan teknologi informasi, aplikasi manajemen referensi telah banyak tersedia seperti aplikasi Mendeley, Zotero, Refwork dan lainnya.

Mahasiswa Fakultas Ekonomi dan Bisnis Islam IAIN Padangsidimpuan yang telah memasuki semester VII dihadapkan pada beban menyusun skripsi. mahasiswa dituntut mendasarkan kegiatan menulis skripsi pada prinsip originalitas. Tantangan ini membutuhkan cara dan teknik yang dapat diaplikasikan untuk memudahkan mahasiwa menyelesaikan skripsi dan terbebas dari plagiarisme. Salah satu bentuk pelanggaran kode etik yang sering dilakukan oleh penulis karya ilmiah salah satunya yaitu plagiarisme (Novitasari, 2019).

Hasil pengamatan dosen pengabdi bahwa di Fakultas Ekonomi dan Bisnis Islam IAIN Padangsidimpuan bahwa sekitar 80 persen mahasiswa masih menggunakan pengutipan referensi secara manual. Hal ini menunjukkan tingkat pemahaman mahasiswa mengenai cara mencari dan mengelola referensi dengan menggunakan aplikasi manajemen referensi baik secara online maupun offline masih minim. Pengutipan referensi dengan cara manual membutuhkan waktu yang lebih lama dibandingkan menggunakan aplikasi manajemen referensi.

Aplikasi Zotero adalah aplikasi manajemen referensi yang memudahkan pengelolaan referensi dan sitasi artikel yang dibutuhkan dalam penelitian. Penggunaan aplikasi Zotero mempermudah penggunaan gaya penulisan referensi secara konsisten dan menjamin pengutipan ke sumber referensi yang tepat sehingga dapat mengurangi kemungkinan terjadi plagiarisme. Plagiarisme yang terjadi sering disebabkan karena faktor ketidaksengajaan yang disebabkan minimnya pengetahuan teknik dan cara pengutipan atau sitasi. Kegiatan sitasi menjadi bagian yang tidak dapat dipisahkan dalam penulisan karya ilmiah. Penggunaan perangkat lunak akan memudahkan peneliti dalam mengelola dokumendokumen referensi yang akan disitasi (Ngibad, 2020). Selain itu, referensi yang disitasi dalam naskah tulisan akan memudahkan penyusunan daftar pustaka. Daftar pustaka menjadi hal yang wajib dalam sebuah karya tulis ilmiah sebagai wujud pengakuan intelektual kepada penulis-penulis lain atas karyannya yang telah digunakan (Purwani, 2013).

Penelitian dan pengabdian kepada masyarakat yang dilakukan sebelumnya terkait pemanfaatan Zotero menunjukkan bahwa pelatihan aplikasi Zotero sangat membantu mahasiswa Magister Ilmu Pemerintahan dalam proses mengerjakan karya ilmiah (Anjali \& Istiqomah, 2020). Penggunaan Zotero meningkatkan kualitas sitasi serta daftar pustaka karya ilmiah yang dihasilkan dan dapat disesuaikan dengan gaya atau format penulisan yang dibutuhkan penulis (Larasati, 2020).

Kegiatan pengabdian kepada masyarakat ini bertujuan untuk meningkatkan kemampuan mahasiswa Fakultas Ekonomi dan Bisnis Islam IAIN Padangsidimpuan dalam memanfaatkan manajemen referensi aplikasi Zotero dalam penulisan skripsi. Dengan kegiatan ini, diharapkan mahasiswa lebih mampu mengoperasikan aplikasi Zotero dan terbantu dalam memilih, menentukan serta mengelola referensi-referensi yang akan disitasi dalam karya ilmiah secara tepat, efektif dan efisien. 
Available online at https://jurnal.stmikroyal.ac.id/index.php/jurdimas

\section{METODE}

Peserta kegiatan pengabdian kepada masyarakat ini yaitu mahasiswa Fakultas Ekonomi dan Bisnis Islam IAIN Padangsidimpuan yang sedang dalam proses menyelesaikan skripsi. Pelatihan ini dilaksaksanakan dalam 1 hari di ruang aula fakultas. Pelatihan dimulai dengan membagikan pretest untuk menilai tingkat pemahaman peserta terkait aplikasi Zotero. Pada akhir pelatihan peserta kembali diberikan postest untuk mengukur tingkat kemampuan peserta setelah mengikuti pelatihan. Secara umu, kegiatan ini dimulai dari perencanaan dilanjutkan dengan pelaksanaan dan diakhiri dengan evaluasi. Lebih lengkapnya, Langkah-langkah pelatihan pemanfaatan manajemen referensi Zotero dijelaskan sebagai berikut.

\section{Perencanaan}

Perencanaan yang dilakukan berkaitan dengan kebutuhan yang diperlukan dalam kegiatan pelatihan. Perencanaan dimulai dengan penentuan jadwal kegiatan, penetapan materi pelatihan, perlengkapan yang diperlukan seperti infokus dan lain sebagainya.

\section{Pelatihan}

Pelatihan dilakukan dalam 1 hari yang dipandu oleh dosen pengabdi Fakultas Ekonomi dan Bisnis Islam IAIN Padangsidimpuan. Materi-materi yang disampaikan dalam pelatihan ini dibagi menjadi dua sesi. Sesi pertama terdiri dari 3 topik pembahasan dan sesi kedua terdiri dari 2 topik pembahasan. Materi-materi tersebut dapat dilihat pada Tabel 1 .

\section{Evaluasi}

Evaluasi dilakukan terhadap
proses pelaksanaan pelatihan yang dilakukan. Evaluasi dilakukan dalam rangka mengukur sejauhmana efektifitas pelaksanaan kegiatan yang dilakukan dalam meningkatkan pemanfaatan aplikasi Zotero oleh mahasiswa yang dalam menulis karya ilmiah. Evaluasi dilakukan dengan menganalisa hasil pretest dan postest yang telah diberikan kepada peserta pelatihan.

Tabel 1. Materi Pelatihan Manajemen Referensi Zotero

\begin{tabular}{|c|c|c|c|}
\hline Sesi ke- & Materi & Metode & Keterangan \\
\hline I & $\begin{array}{l}\text { 1. Gambaran Umum Manajemen } \\
\text { Referensi Zotero. } \\
\text { 2. Perbedaan Pengelolaan Referensi } \\
\text { secara Manual dan Menggunakan } \\
\text { Manajemen Referensi. } \\
\text { 3. Tujuan dan Manfaat Aplikasi Zotero }\end{array}$ & $\begin{array}{l}\text { Ceramah dan } \\
\text { tanya jawab }\end{array}$ & $100 \%$ teori \\
\hline II & $\begin{array}{l}\text { 1. Praktek Menginstal Aplikasi Zotero } \\
\text { 2. Praktek Mengoperasikan Aplikasi } \\
\text { Zotero }\end{array}$ & $\begin{array}{l}\text { Praktek dan } \\
\text { Pendampingan }\end{array}$ & $\begin{array}{l}100 \% \\
\text { Praktek }\end{array}$ \\
\hline
\end{tabular}




\section{PEMBAHASAN}

Kegiatan pelatihan pemanfaatan manajemen referensi Zotero dilakukan di Fakultas Ekonomi dan Bisnis Islam IAIN Padangsidimpuan dilakukan dengan pemaparan materi dan dilanjutkan dengan praktek menginstal dan mengoperasikan aplikasi Zotero. Materi yang disampaikan dikelompokkan menjadi dua sesi.

Materi yang disampaikan pada sesi pertama mengenai gambaran umum, perbedaan pengelolaan referensi secara manual dan menggunakan manajemen referensi serta tujuan dan manfaat menggunakan aplikasi Zotero. Penyampaian materi pada sesi pertama dilanjutkan dengan praktek pada sesi kedua. Materi yang disampaikan dosen pengabdi disimak dengan baik oleh peserta pelatihan.

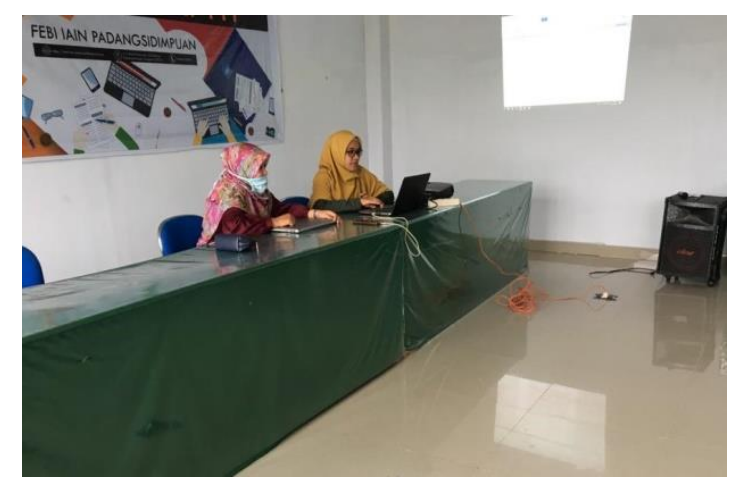

Gambar 1. Pemaparan Materi

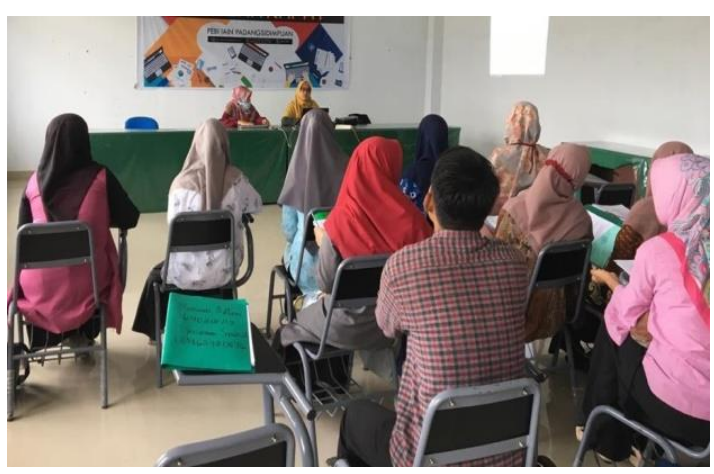

Gambar 2. Peserta Menyimak Materi Pelatihan
Karya ilmiah memiliki beberapa bentuk diantaranya skripsi. Skripsi menjadi syarat wajib bagi mahasiswa dalam menyelesaikan pendidikan di perguruan tinggi. Skripsi merupakan karya karya ilmiah yang disusun oleh mahasiswa program strata-1 yang pembahasannya terkait tentang satu bidang tertentu yang didasarkan pada hasil penelitian lapangan, hasil eksperimen dan kajian literatur (Huda, 2011). Pada umumnya pembahasan dalam skripsi berkaitan dengan bidang studi yang diambil mahasiswa yang bersangkutan sebagai bentuk upaya pendalaman disiplin ilmu.

Penulisan karya ilmiah membutuhkan sitasi dan pengutipan untuk memperkaya referensi yang digunakan dalam karya tersebut. Keahlian dalam manajemen referensi menjadi sebuah keharusan bagi setiap mahasiswa untuk memudahkan mencari, menentukan serta mengelola referensi secara mudah, tepat dan efektif (Kosasi, 2019). Pengutipan dalam karya ilmiah menjadi bagian yang sangat penting. Kegiatan mengumpulkan referensi yang tepat hingga memuat referensi tersebut ke dalam suatu naskah tulisan merupakan pekerjaan yang menyita waktu dan usaha yang tidak sedikit (Aidid, Bustan, \& Ruliana, 2020). Pencarian referensi dan mengelola referensi menjadi lebih mudah dilakukan dengan menggunakan perangkat manajemen referensi. Tool atau perangkat tersebut bekerja dengan cara mendigitalisasi koleksi referensi yang akan digunakan sehingga kegiatan mencari dan mengumpulkan referensi akan lebih efisien (Marshall, 2020). Selain itu, perangkat tersebut juga memudahkan penulis untuk melacak keaslian dan kualitas referensi yang akan digunakan dalam karya ilmiah dan dapat dikelompokkan berdasarkan topik 
Available online at https://jurnal.stmikroyal.ac.id/index.php/jurdimas

tertentu (Agustiana, Tika, \& Wibawa, 2018).

Zotero merupakan aplikasi yang dikembangkan dengan tujuan nonkomersial, sehingga aplikasi ini dapat diperoleh secara gratis (Basri \& Mus, 2019). Aplikasi Zotero dapat mendeteksi konten-konten yang terdapat dalam halaman muka suatu website. Informasi yang tersedia dalam halaman website dan dibutuhkan dalam penulisan karya ilmiah dapat disimpan ke dalam perangkat komputer yang dikumpulkan dalam perpustakaan digital dengan mudah. Penelitian-penelitian atau jurnal yang akan dibutuhkan untuk pengutipan dan sitasi karya ilmiah juga dapat disimpan dalam perpustakaan yang dapat dipergunakan dengan mudah (Dwiningsih \& Tukiran, 2019). Daftar pustaka suatu karya ilmiah yang biasanya membutuhkan waktu pengerjaan yang lebih lama menjadi lebih mudah dengan menggunakan aplikasi Zotero karena aplikasi ini akan berkerja secara otomatis dengan mengikuti gaya sitasi tertentu
(Pramiastuti, Rejeki, \& Pratiwi, 2020). Dalam pemaparan materi disampaikan bahwa terdapat banyak pilihan gaya sitasi. Gaya sitasi yang digunakan disesuaikan dengan kebutuhan. Ragam gaya sitasi yang dapat digunakan dapat dilihat pada Gambar 3.

Gambar 3 menunjukkan bahwa Zotero menyediakan banyak gaya sitasi yang dapat digunakan sesuai dengan kebutuhan pengguna. Gaya sitasi tersebut seperti American Chemical Society, American Chemical Association $11^{\text {th }}$ Edition, American Pshychological Association (APA) $7^{\text {th }}$ Edition, Chicago Manual of Style, dan lain sebagainya. Pengutipan dan daftar pustaka akan menyesuaikan dengan gaya sitasi yang dipilih.

Pretest dan postest diberikan dalam kegiatan pelatihan ini. Hal ini dilakukan untuk mengukur pengaruh pelatihan terhadap tingkat pemahaman peserta dalam menggunakan aplikasi Zotero dalam mengelola referensi karya ilmiah.

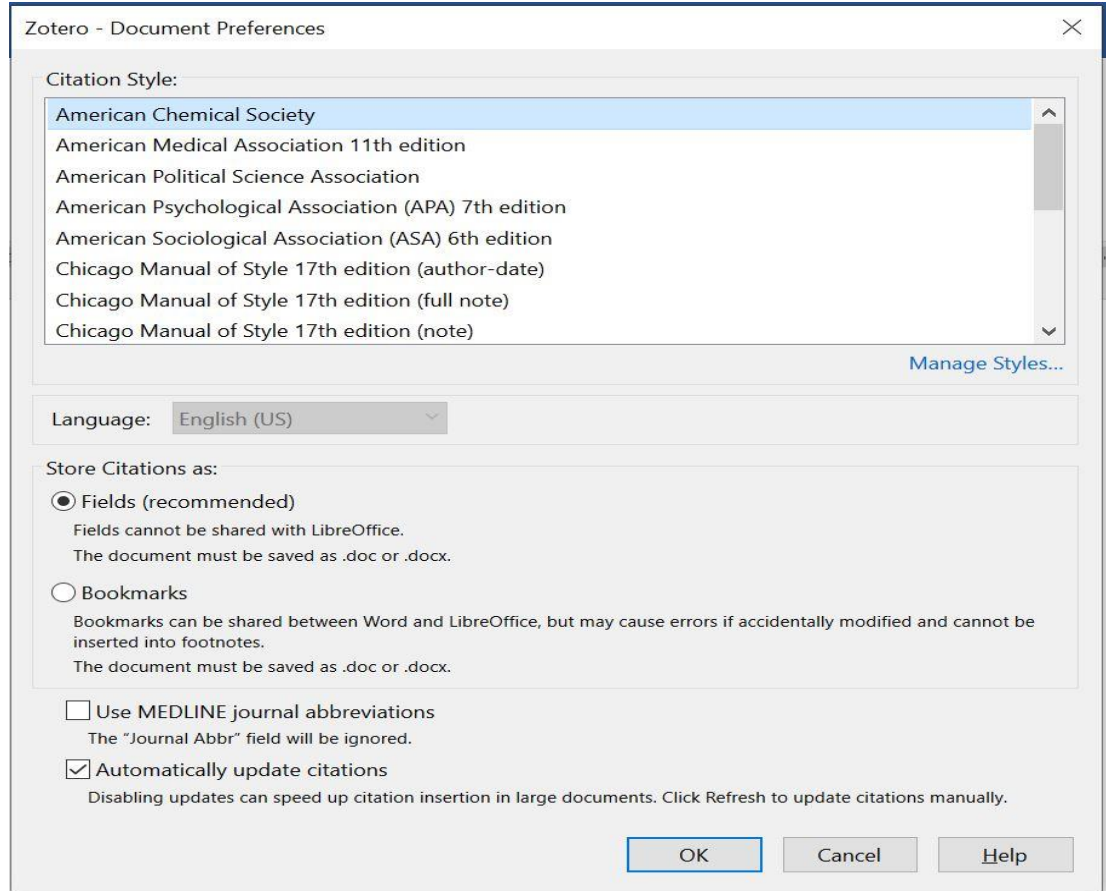

Gambar 3. Gaya Sitasi Aplikasi Zotero 
Available online at https://jurnal.stmikroyal.ac.id/index.php/jurdimas

Berdasarkan hasil pretest dan postest yang telah dilakukan diperoleh hasil bahwa pelatihan ini berdampak positif terhadap kemampuan mahasiswa dalam memanfaatkan aplikasi Zotero. Dimana kemampuan mahasiswa dalam menggunakan dan mengelola referensi menjadi semakin baik. Mahasiswa juga semakin mahir dalam mencari serta menentukan referensi yang tepat yang akan disitasi dalam karya ilmiahnya. Hasil pretest dan postest peserta pelatihan disajikan dalam Gambar 4.

Gambar 4 menunjukkan rata-rata nilai pretest dan postest keselururuhan peserta pelatihan. Hasil tersebut menyatakan bahwa mahasiswa sebelum mengikuti pelatihan kurang mengetahui tujuan, manfaat dan cara menggunakan aplikasi manajemen referensi Zotero. Serta kurang mengetahui manajemen referensi sangat membantu pengelolaan referensi dan memudahkan mendapatkan sumber kutipan referensi. Mahasiswa setelah mengikuti pelatihan semakin paham bahwa aplikasi Zotero memiliki beragam gaya sitasi dan memudahkan dalam mengelola daftar pustaka sebuah karya ilmiah.

Secara umum, kegiatan pelatihan pemanfaatan Zotero perlu terus dilakukan kepada mahasiswa. Hal ini bertujuan untuk mengarahkan cara penulisan karya mahasiswa yang yang lebih baik yaitu memenuhi standar internasional. Untuk memenuhi standar internasional, berbagai perangkat aplikasi dapat digunakan dalam sitasi ilmiah (Darmalaksana, 2020). Pengutipan menggunakan aplikasi Zotero dalam penulisan karya ilmiah telah mengarah pada penulisan karya ilmiah sesuai standar internasional (Eve, 2020). Saat ini, penulisan karya ilmiah telah digalakkan untuk menggunakan aplikasi mutakhir seperti Zotero dan Mendeley (Saputra, 2019) yang difungsikan dengan akses internet. Keberadaan aplikasi manajemen referensi memberikan kemudahan bagi penggiat penelitian mulai dari proses penulisan karya ilmiah hingga mempublikasikannya (Hafid et al., 2018).

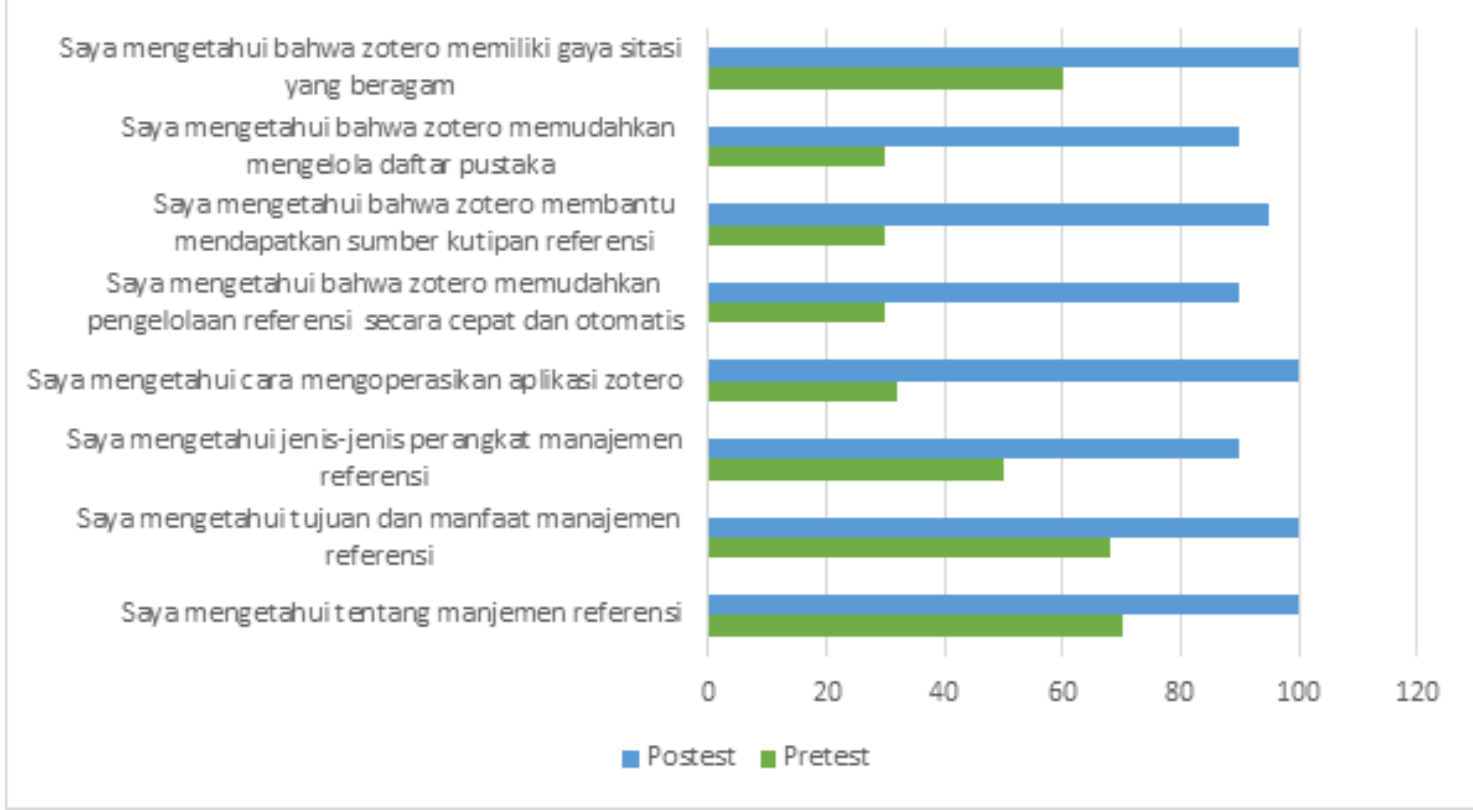

Gambar 4. Hasil Pretest dan Postest Pelatihan Zotero 
Available online at https://jurnal.stmikroyal.ac.id/index.php/jurdimas

\section{SIMPULAN}

Kegiatan pelatihan pemanfaatan manajemen referensi Zotero ini telah meningkatkan kemampuan mahasiswa dalam mengoperasikan aplikasi Zotero. Kemampuan mahasiswa mengelola referensi dan melakukan sitasi dalam karya ilmiah setelah mengikuti kegiatan pelatihan menjadi lebih baik dibandingkan sebelum mengikuti pelatihan. Peningkatan kemampuan tersebut dinilai berdasarkan hasil pretest dan postest peserta pelatihan. Secara umum, kegiatan pelatihan ini telah terlaksana dengan baik dan mencapai tujuan yang diharapkan. Dengan demikian, kegiatan pelatihan ini telah memberikan manfaat bagi mahasiswa Fakultas Ekonomi dan Bisnis Islam IAIN Padangsidimpuan dalam meningkatkan kemampuan mahasiswa memanfaatkan Zotero dalam mengelola referensi yang dibutuhkan dalam penulisan karya ilmiah.

\section{UCAPAN TERIMA KASIH}

Saya mengucapkan terima kasih yang tidak terhingga kepada Fakultas Ekonomi dan Bisnis Islam IAIN Padangsidimpuan yang terus memberikan dukungan dalam mensukseskan kegiatan pengabdian kepada masyarakat ini.

\section{DAFTAR PUSTAKA}

Agustiana, I. G. A. T., Tika, I. N., \& Wibawa, I. M. C. (2018). Pelatihan Membuat Daftar Isi dan Daftar Pustaka dengan Sekali Klik Berbantuan Mendeley Bagi Para Dosen PTS dalam Menyusun Artikel dan Laporan Penelitian Se-Kabupaten Buleleng.
International Journal of Community Service Learning, 2(2), 116-123.

Aidid, M. K., Bustan, M. N., \& Ruliana, R. (2020). Manajemen Referensi dengan Aplikasi Zotero. DEDIKASI, 22(2).

Anjali, M. E. C., \& Istiqomah, Z. (2020). Implementasi Pelatihan Aplikasi Zotero Di Perpustakaan Universitas Muhammadiyah Yogyakarta Bagi Mahasiswa Magister Ilmu Pemerintahan. Publication Library and Information Science, 3(2), 97103. doi: $10.24269 /$ pls.v3i2.2434

Basri, S., \& Mus, S. (2019). Manajemen referensi penulisan karya tulis ilmiah Mahasiswa STKIP-PI Makassar. Seminar Nasional Pengabdian Kepada Masyarakat, 2018(8).

Darmalaksana, W. (2020). Sitasi Ilmiah Menggunakan Perangkat References pada Microsoft Word. Jurnal Kelas Menulis UIN Sunan Gunung Djati Bandung, 1. Retrieved from http://digilib.uinsgd.ac.id/32339/

Dwiningsih, K., \& Tukiran, T. (2019). Peningkatan Kualitas Publikasi Ilmiah Dan Penelitian Bagi Guru Sma Melalui Pelatihan Pemanfaatan Software Zotero. Jurnal ABDI: Media Pengabdian Kepada Masyarakat, 4(2), 85-90.

Eve, M. P. (2020). Zotero and autodownloading open access books. Martineve. Com.

Hafid, A., Mukhtar, H., Hayami, R., Fatma, Y., Unik, M., Hasanuddin, H., \& Rizki, Y. (2018). Peningkatan Kualitas Publikasi Ilmiah Dan Penelitian Bagi Guru Slta Dengan Pemanfaatan Software Referensi. Jurnal 
Available online at https://jurnal.stmikroyal.ac.id/index.php/jurdimas

Pengabdian UntukMu NegeRI, 2(2), 77-82. doi: 10.37859/jpumri.v2i2.1003

Huda, M. (2011). Cooperative learning. Yogyakarta: Pustaka Belajar.

Kosasi, S. (2019). Pemanfaatan Aplikasi Mendeley desktop Mengelola Referensi Publikasi Karya Ilmiah Mahasiswa. SNPMas: Seminar Nasional Pengabdian Pada Masyarakat, 64-74.

Larasati, A. (2020). Peningkatan Kemampuan Mengoperasikan Reference Management Software Zotero Dan End-Note Untuk Guru Smkn 6 Malang. Jurnal Pengabdian Kepada Masyarakat, 26(1), 28-33. doi: 10.24114/jpkm.v26i1.15777

Marshall, C. (2020). Citation Management Software Raises Library Profile. Journal of Hospital Librarianship, 1-5.

Ngibad, K. (2020). Pelatihan Mendeley secara Online bagi Mahasiswa
FIKES UMAHA di Masa Pandemi Covid-19. Jurnal Pengabdian Dan Pemberdayaan Nusantara (JPPNu), 2(1), 110116.

Novitasari, N. F. (2019). Program Pelatihan Penulisan Artikel Ilmiah: Menuju Guru Berkualitas. Jurnal Pengabdian Pada Masyarakat, 4(3), 255-266. doi: 10.30653/002.201943.152

Pramiastuti, O., Rejeki, D. S., \& Pratiwi, A. (2020). Pengenalan Dan Pelatihan Sitasi Karya Ilmiah Menggunakan Aplikasi Mendeley. JABI: Jurnal Abdimas Bhakti Indonesia, 1(1), 24-30. doi: 10.36308/abp.v1i1.178

Purwani. (2013). Membuat Sitasi Dan Daftar Pustaka. Retrieved from https://d1wqtxts1xzle7.cloudfront.

Saputra, A. (2019). Menajemen Sumber Referensi Ilmiah Menggunakan Aplikasi Zotero. 